\title{
Is There Any Effect of the Physician Performing Embryo Transfer in IVF-ICSI Treatment: A Prospective Cohort Study
}

\section{Existe algum efeito do médico que realiza a transferência de embriões no tratamento de FIV-ICSI: Um estudo de} coorte prospectivo

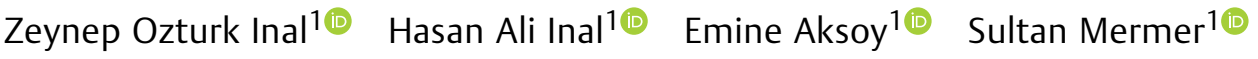 \\ ${ }^{1}$ Department of Reproductive Endocrinology, In Vitro Fertilization \\ Address for correspondence Hasan Ali Inal, M.D., IVF Unit, Konya \\ Unit, Konya Training and Research Hospital, Konya, Turkey \\ Training and Research Hospital, 42090, Meram Yeni Yol, Konya, Turkey \\ (e-mail: dr.hasanaliinal@yahoo.com).
} Rev Bras Ginecol Obstet 2022;44(1):19-24.

\begin{abstract}
Keywords

- assisted reproductive technology

- embryo transfer

- infertility physicians

- pregnancy rate

Objective To evaluate whether there is an effect of the physician who transfers the embryos on pregnancy rates in in vitro fertilization-intracytoplasmic sperm injection (IVF-ICSI) treatment.

Methods A total of 757 participants were analyzed between 2012 and 2017. Participants were classified according to 3 physicians who transferred the embryos: ([group $1=164$ patients]; [group $2=233$ patients]; [group $3=360$ patients]). Baseline parameters and IVF-ICSI outcomes were compared between the groups.

Results No differences were determined between the groups regarding the baseline parameters (age, age subgroups [20-29, 30-39, and $\geq 40$ years old)], body mass index (BMI), smoking status, infertility period, cause of infertility, baseline follicle stimulating hormone, luteinizing hormone, estradiol $\left(E_{2}\right)$, thyroid stimulating hormone, prolactin levels, antral follicle count, duration of stimulation, stimulation protocol, gonadotropin dose required, maximum $E_{2}$ levels, progesterone levels, endometrial thickness on human chorionic gonadotropin (hCG) administration and transfer days ( $p>0.05)$. The numbers of oocytes retrieved, metaphase II (MII), 2 pronucleus (2PN), transferred embryo, fertilization rate, day of embryo transfer, the catheter effect and embryo transfer technique, and clinical pregnancy rates (CPRs) were also comparable between the groups ( $p>0.05)$.

Conclusion Our data suggests that the physician who transfers the embryos has no impact on CPRs in patients who have undergone IVF-ICSI, but further studies with more participants are required to elucidate this situation.
\end{abstract}

received

October 7, 2020

accepted

October 6, 2021
DOI https://doi.org/

10.1055/s-0041-1740473. ISSN 0100-7203. (c) 2022. Federação Brasileira de Ginecologia e Obstetrícia. All rights reserved.

This is an open access article published by Thieme under the terms of the Creative Commons Attribution License, permitting unrestricted use, distribution, and reproduction so long as the original work is properly cited. (https://creativecommons.org/licenses/by/4.0/)

Thieme Revinter Publicações Ltda., Rua do Matoso 170, Rio de Janeiro, RJ, CEP 20270-135, Brazil 


\section{Resumo}

\author{
Palavras-chave \\ - tecnologia \\ reprodutiva \\ assistida \\ - transferência de \\ embrião \\ - médicos de \\ infertilidade \\ - taxa de gravidez
}

Objetivo Avaliar se há ou não efeito do médico que realiza a transferência de embriões nas taxas de gravidez no tratamento com fertilização in vitro-injeção intracitoplasmática de espermatozoide (FIV-ICSI, na sigla em inglês).

Métodos Um total de 757 participantes foram analisados entre 2012 e 2017. Os participantes foram classificados de acordo com 3 médicos que transferiram os embriões: ([grupo $1=164$ pacientes]; [grupo $2=233$ pacientes]; [grupo $3=360$ pacientes]). Parâmetros basais e resultados de FIV-ICSI foram comparados entre os grupos.

Resultados Nenhuma diferença foi determinada entre os grupos nos parâmetros basais (idade, subgrupos de idade [20-29, 30-39 e $\geq 40$ anos)], índice de massa corporal (IMC), tabagismo, período de infertilidade, causa da infertilidade, hormônio folículo estimulante basal , hormônio luteinizante, estradiol (E2), hormônio estimulador da tireoide, níveis de prolactina, contagem de folículos antrais, duração da estimulação, protocolo de estimulação, dose de gonadotrofina necessária, níveis máximos de E2, níveis de progesterona e espessura endometrial na administração de hCG e nos dias de transferência $(p>0,05)$. O número de oócitos recuperados, MII e $2 \mathrm{PN}$, embrião transferido, taxa de fertilização, dia da transferência do embrião, o efeito do cateter e a técnica de transferência de embrião e taxas clínicas de gravidez (RCPs) também foram comparáveis entre os grupos $(p>0,05)$.

Conclusão Nossos dados sugerem que o médico que transfere os embriões não tem impacto sobre as RCPs em pacientes que se submeteram a FIV-ICSI, mas mais estudos com mais participantes são necessários para elucidar esta situação.

\section{Introduction}

Despite all of the developments in assisted reproductive technology (ART) since the first live birth following in vitro fertilization (IVF) in 1978, pregnancy rates have remained at between $\sim 35$ and $45 \%{ }^{1-5}$ In ART cycles, the method of embryo transfer (ET) is important for clinical pregnancy success in addition to features such as age, endometrial receptivity of the infertile woman, and embryo quality. ${ }^{6-9}$ It has been claimed that faulty ET is responsible for between 25 and 30\% of failed implantations, related either to the catheter application technique or to the experience of the clinician performing the ET procedure. ${ }^{5,6,10}$ To minimize possible negative effects of different physicians on the clinical pregnancy rate $(\mathrm{CPR})$ in $\mathrm{ET}$, these procedures have been standardized by assisted reproduction clinics. Nevertheless, some studies have suggested that the physician who performs the ET may affect CPR success. ${ }^{11-13}$ In the present study, we aimed to evaluate the effect of the physician who transfers the embryos on pregnancy rates in IVF-intracytoplasmic sperm injection (IVF-ICSI) treatment.

\section{Methods}

\section{Study Participants and Data Collection}

The present prospective study was performed at the Reproductive Endocrinology Department of the Ali Kemal Belviranli Maternal Women's Health and Children's Hospital. Outcomes of 757 fresh ICSI cycles were reviewed between January 2012 and December 2017. The inclusion criteria were participants aged between 20 and 44 years old, body mass index (BMI) between 18 and $35 \mathrm{~kg} / \mathrm{m}^{2}$, regular menstrual cycles, no uterine abnormalities in the ultrasound, and normal baseline hormonal levels. Participants were excluded from the study if they were $\geq 45$ years, with a BMI $\geq$ $35 \mathrm{~kg} / \mathrm{m}^{2}$, or had any significant illness or metabolic disorders. Ethical board approval was granted from the institutional review board (2012/57). Written and oral informed consent was given from the participants. Data were obtained for age, BMI $\left(\mathrm{kg} / \mathrm{m}^{2}\right)$, smoking status, infertility period, cause of infertility, baseline at day 3 for follicle-stimulating hormone (FSH), luteinizing hormone (LH), and estradiol $\left(\mathrm{E}_{2}\right)$ levels, thyroid-stimulating hormone (TSH), prolactin, antral follicle count, stimulation parameters, IVF-ICSI outcomes, and CPR.

\section{Ovarian Stimulation and Oocyte Retrieval}

Controlled ovulation stimulation was negotiated using the gonadotropin-releasing hormone agonist (GnRHa) or the flexible gonadotropin-releasing hormone antagonist (GnRHant) protocol.

\section{Embryo Transfer Procedure}

Three senior physicians performed the ETs accompanied by ultrasonographic guidance (USG) (Logiq 200 Pro, General Electric, Seoul, South Korea) using an ET catheter system. A sterile speculum was introduced in the vagina in the lithotomy position, then the vagina and the cervix were cleaned using sterile cotton swabs. An embryologist loaded the embryos into a soft transfer catheter that was given to the 
ET physician, who deposited the embryos $\sim 10 \mathrm{~mm}$ from the uterine fundus under USG. The catheter was gently removed after 5 seconds. In cases of ET with external guidance, an initial catheter with inner sheath was inserted into the external cervical os, and then advanced through the cervical canal and the internal os to $10 \mathrm{~mm}$ of the uterine fundus under USG. The internal sheath was withdrawn, and a second catheter loaded with embryos was introduced in its place and advanced to $\sim 10 \mathrm{~mm}$ from the uterine fundus, where the embryos were deposited. Difficult transfers required the use of a stylet in addition to this form of external guidance. All catheters were immediately checked for retained embryos and blood, and the patient remained in the Trendelenburg position for $\sim 10$ minutes. Patients who used the tenaculum were excluded from the study. Progesterone in the form of Crinone $8 \%$ gel (Serono, Istanbul, Turkey) at a daily dose of $90 \mathrm{mg}$ for 14 days was given for luteal phase support. Baseline parameters and IVF-ICSI outcomes were compared between the groups. Clinical pregnancy was accepted as those with a gestational sac accompanying fetal heartbeat on ultrasound examination at between 4 and 5 weeks after the ET. The CPR was defined as the number of clinical pregnancy cycles/number of embryo transfer cycles $\times 100 \%$. The number of embryos transferred ( $\leq 2$ per patient) complied with the Turkish national regulations. The subjects were classified according to 3 physicians who transferred the embryos: ([group $1=164$ patients]; [group $2=233$ patients]; [group $3=360$ patients]).

\section{Statistical Analysis}

The statistical analyses were performed using SPSS for Windows, version 15.0 (SPSS Inc., Chicago, IL, USA). The Shapiro-Wilk test was used to examine the continuous variables with normal and non-normal distributions. The one-way analysis of variance (ANOVA) was preferred for the normally distributed continuous variables, while the Kruskal-Wallis test was used for the non-normally distributed continuous variables. Categorical data were analyzed by the Pearson chi-squared test, and the Fisher exact test was applied if the expected frequency was $<5$ in $>20 \%$ of all

Table 1 Demographic and stimulation characteristics of the patients

\begin{tabular}{|c|c|c|c|c|c|}
\hline & & $\begin{array}{l}\text { Group } 1 \\
(n=164)\end{array}$ & $\begin{array}{l}\text { Group } 2 \\
(n=233)\end{array}$ & $\begin{array}{l}\text { Group } 3 \\
(n=360)\end{array}$ & p-value \\
\hline \multicolumn{2}{|l|}{ Age (years old) } & $30.31 \pm 5.48$ & $29.21 \pm 4.54$ & $29.77 \pm 4.31$ & 0.069 \\
\hline \multirow[t]{3}{*}{ Age (years old) subgroups } & $20-29(\%)$ & $52.4 \%$ & $59.6 \%$ & $54.2 \%$ & 0.529 \\
\hline & $30-39(\%)$ & $45.1 \%$ & $38.6 \%$ & $44.4 \%$ & \\
\hline & $\geq 40(\%)$ & $2.4 \%$ & $1.8 \%$ & $1.4 \%$ & \\
\hline \multicolumn{2}{|l|}{ BMI $\left(\mathrm{kg} / \mathrm{m}^{2}\right)$} & $26.16 \pm 4.67$ & $25.50 \pm 4.31$ & $26.18 \pm 4.82$ & 0.190 \\
\hline \multicolumn{2}{|l|}{ Smoking rate (\%) } & $4.5 \%$ & $6.4 \%$ & $9.7 \%$ & 0.110 \\
\hline \multicolumn{2}{|l|}{ Duration of infertility (years) } & $6.42 \pm 4.02$ & $6.49 \pm 3.18$ & $6.30 \pm 3.49$ & 0.410 \\
\hline \multirow[t]{4}{*}{ Etiology of infertility (\%) } & Male factor & $40.2 \%$ & $41.7 \%$ & $31.9 \%$ & \\
\hline & Tubal factor & $4.3 \%$ & $1.8 \%$ & $1.4 \%$ & 0.069 \\
\hline & Unexplained & $35.4 \%$ & $37.7 \%$ & $42.5 \%$ & \\
\hline & Poor responder & $20.1 \%$ & $18.8 \%$ & $24.2 \%$ & \\
\hline \multicolumn{2}{|l|}{ Baseline-FSH (IU/mL) } & $6.94 \pm 1.94$ & $7.08 \pm 2.19$ & $7.29 \pm 2.49$ & 0.103 \\
\hline \multicolumn{2}{|l|}{ Baseline-LH (IU/mL) } & $5.14 \pm 2.71$ & $5.48 \pm 2.93$ & $5.77 \pm 2.97$ & 0.064 \\
\hline \multicolumn{2}{|l|}{ Baseline-estradiol (pg/mL) } & $43.27 \pm 13.15$ & $45.62 \pm 16.54$ & $44.79 \pm 17.36$ & 0.124 \\
\hline \multicolumn{2}{|l|}{ Antral follicle count } & $6.61 \pm 2.48$ & $6.63 \pm 2.38$ & $6.28 \pm 2.58$ & 0.395 \\
\hline \multicolumn{2}{|l|}{$\mathrm{TSH}(\mu \mathrm{IU} / \mathrm{mL})$} & $2.15 \pm 1.04$ & $2.20 \pm 1.07$ & $2.19 \pm 1.17$ & 0.885 \\
\hline \multicolumn{2}{|l|}{ Prolactin (ng/mL) } & $14.74 \pm 7.19$ & $15.62 \pm 7.93$ & $15.53 \pm 10.20$ & 0.224 \\
\hline \multirow[t]{2}{*}{ Stimulation protocol (\%) } & Long & $24.5 \%$ & $21.1 \%$ & $17.1 \%$ & \\
\hline & Antagonist & $75.5 \%$ & $78.9 \%$ & $80.8 \%$ & 0.118 \\
\hline \multicolumn{2}{|c|}{ Duration of stimulation (days) } & $10.27 \pm 1.42$ & $9.93 \pm 1.84$ & $10.13 \pm 1.61$ & 0.101 \\
\hline \multicolumn{2}{|c|}{ Gonadotropin dose (IU) } & $2037.62 \pm 705.15$ & $1861.35 \pm 902.89$ & $1921.41 \pm 816.44$ & 0.109 \\
\hline \multicolumn{2}{|c|}{ Estradiol levels on day hCG (pg/mL) } & $2051.67 \pm 1110.13$ & $2002.62 \pm 1109.04$ & $1859.54 \pm 1177.84$ & 0.126 \\
\hline \multicolumn{2}{|c|}{ Progesterone levels on day hCG (pg/mL) } & $0.86 \pm 0.38$ & $0.85 \pm 0.40$ & $0.79 \pm 0.39$ & 0.098 \\
\hline \multicolumn{2}{|c|}{ Endometrial thickness on day hCG (mm) } & $10.56 \pm 1.64$ & $10.51 \pm 1.61$ & $10.27 \pm 1.89$ & 0.130 \\
\hline \multicolumn{2}{|c|}{ Endometrial thickness on transfer day (mm) } & $10.62 \pm 1.78$ & $11.01 \pm 1.73$ & $10.61 \pm 1.90$ & 0.105 \\
\hline
\end{tabular}

Abbreviations: BMI, body mass index; FSH, follicle stimulating hormone; LH, luteinizing hormone; hCG, human chorionic gonadotropine; TSH, thyroid stimulating hormone.

*Statistically significant. 
22 Effect of the Physician Performing Embryo Transfer in IVF-ICSI Treatment Inal et al.

cells. The continuous variables were presented as mean \pm standard deviation (SD), and the categorical variables were presented as the number of cases and percentages. The Bonferroni adjustment was performed to control the type I errors for all possible multiple comparisons. A $p$-value $<0.05$ was accepted as statistically significant.

\section{Results}

A total of 56 patients were excluded from the study, specifically those $\geq 45$ years old $(n=19)$, with BMI $\geq 35 \mathrm{~kg} / \mathrm{m}^{2}$ $(n=14)$, with systemic disease $(n=9)$, endocrine or metabolic disorders $(n=6)$, use of tenaculum $(n=5)$, and concomitant medication $(n=3)$. The remaining 757 participants were classified into the three ET groups and their outcomes were analyzed (-Fig. 1).

A comparison of the sociodemographic and stimulation characteristics of the participants is provided in - Table 1. There was no difference between the groups regarding age, age subgroups (20-29, 30-39, and $\geq 40$ years old), BMI, smoking status, infertility period, cause of infertility, base- line $\mathrm{FSH}, \mathrm{LH}, \mathrm{E}_{2}, \mathrm{TSH}$, prolactin levels, antral follicle count, stimulation day, stimulation protocol, gonadotropin dose required, maximum $E_{2}$ and progesterone levels, and endometrial thickness on hCG administration and transfer days $(p>0.05)$.

The reproductive outcomes of the participants are summarized in - Table 2. The numbers of oocytes retrieved, MII and 2PN, transferred embryo, fertilization rate, the ET day, the catheter effect and ET technique, and the CPR were comparable between the groups $(p>0.05)$.

\section{Discussion}

The present study aimed to investigate whether there is an effect of the physician who transfers the embryos on pregnancy rates in IVF-ICSI treatment. We found no such impact in the present study. There are several studies on this topic with contradictory results; some have shown that the physician factor can have as significant an effect on CPR in IVFICSI cycles as clinical and embryological features, ${ }^{6,14,15}$ but contrasting results have also been reported. ${ }^{12,16,17}$

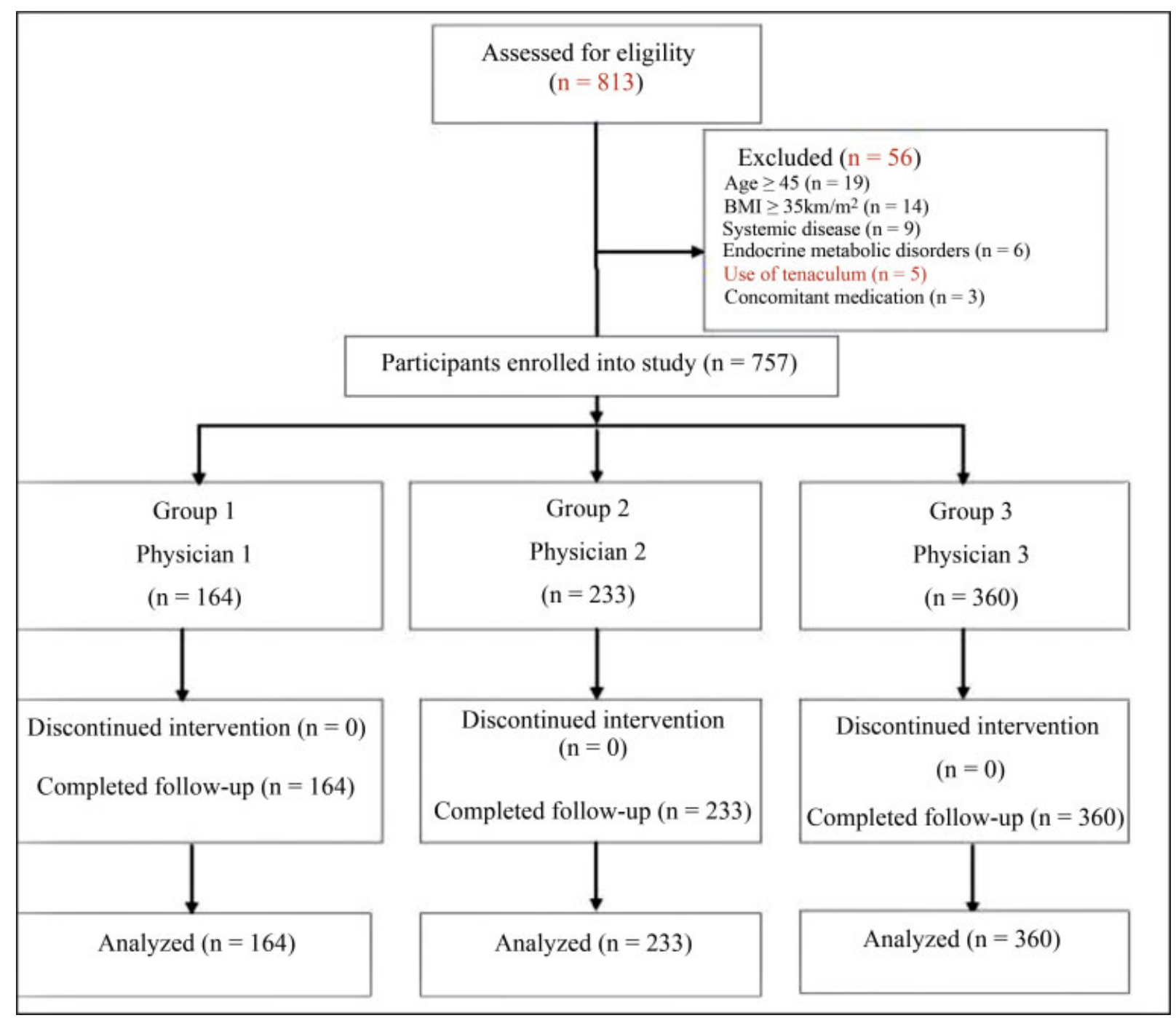

Fig. 1 Enrollment and follow-up of the study subjects. 
Table 2 Laboratory and reproductive outcome parameters of the patients

\begin{tabular}{|c|c|c|c|c|c|}
\hline & & $\begin{array}{l}\text { Group } 1 \\
(n=164)\end{array}$ & $\begin{array}{l}\text { Group } 2 \\
(n=233)\end{array}$ & $\begin{array}{l}\text { Group } 3 \\
(n=360)\end{array}$ & p-value \\
\hline \multicolumn{2}{|l|}{ Number of oocytes retrieved } & $9.67 \pm 6.59$ & $8.92 \pm 4.87$ & $9.16 \pm 5.39$ & 0.112 \\
\hline \multicolumn{2}{|l|}{ Number of MII oocytes } & $8.02 \pm 4.65$ & $7.30 \pm 4.22$ & $7.10 \pm 4.38$ & 0.144 \\
\hline \multicolumn{2}{|l|}{2 Pronucleus } & $5.19 \pm 3.43$ & $4.65 \pm 3.08$ & $4.86 \pm 3.32$ & 0.276 \\
\hline \multicolumn{2}{|l|}{ Fertilization rate $(\%)$} & $63.98 \pm 22.30$ & $66.80 \pm 23.88$ & $65.35 \pm 25.01$ & 0.424 \\
\hline \multicolumn{2}{|l|}{ Grade I embryo (\%) } & $64.8 \%$ & $67.9 \%$ & $66.7 \%$ & 0.821 \\
\hline \multicolumn{2}{|l|}{ Number of embryos transferred } & $1.21 \pm 0.40$ & $1.18 \pm 0.86$ & $1.17 \pm 0.38$ & 0.821 \\
\hline \multirow[t]{3}{*}{ Days of embryo transfer (\%) } & 2 & $12.6 \%$ & $4.5 \%$ & $3.1 \%$ & \\
\hline & 3 & $78.0 \%$ & $83.5 \%$ & $87.1 \%$ & 0.193 \\
\hline & 5 & $9.4 \%$ & $12.1 \%$ & $9.8 \%$ & \\
\hline \multirow[t]{3}{*}{ Embryo transfer technique (\%) } & Easy transfer with a soft catheter & $21.1 \%$ & $18.3 \%$ & $20.8 \%$ & \\
\hline & After external guidance transfer & $69.1 \%$ & $73.3 \%$ & $70.1 \%$ & 0.118 \\
\hline & Difficult transfer with a stylet & $9.8 \%$ & $8.4 \%$ & $9.1 \%$ & \\
\hline \multicolumn{2}{|c|}{ The presence of blood in the catheter (\%) } & $2.4 \%$ & $3.1 \%$ & $3.6 \%$ & 0.466 \\
\hline \multicolumn{2}{|c|}{ Clinical pregnancy rate (\%) } & $34.8 \%$ & $37.7 \%$ & $35.1 \%$ & 0.771 \\
\hline
\end{tabular}

Hearns-Stokes et al. ${ }^{17}$ found that CPR was statistically different, at 17.0 and $54.3 \%$, according to the physician performing the procedure in their evaluation of 854 fresh ETs in 617 IVF-ICSI cycles. However, possible confounding factors such as age and embryo quality, which may have caused this significant difference, were not analyzed. In another study, 1,850 IVF-ICSI cycles were retrospectively evaluated over 2 years, and CPR rates ranged between 13.2 and $37.4 \%$ among the physicians who had performed the ETs. When standard training was provided to the physicians with low CPRs in the $1^{\text {st }}$ year, the rates increased. ${ }^{12}$ However, other factors that could affect the CPR were once more not taken into account in the statistical analysis.

In some Nordic countries, ET is performed by midwives and physicians to share the workload, and in a study comparing 102 ETs split equally among the groups, no difference was found in terms of CPR, at 31.0 and $29.0 \%$, respectively. ${ }^{18}$ In a study of 679 nurses and 92 physicians in the United Kingdom, 771 ETs were evaluated and the CPR rate was found to be higher in the nurse group, at 36.2 versus $29.4 \% .{ }^{11}$ Since the ET procedures in our IVF center were all performed by physicians, these comparisons could not be performed in our study.

In a study evaluating 204 ETs performed by 5 trainee providers, no significant CPR difference was found between them. ${ }^{13}$ Since our clinic does not train IVF physicians, no such comparison was performed on our data. Elsewhere, a study comparing the effect on CPR of 2 physicians performing 485 ETs found no difference, at 36.1 and $20.6 \% .{ }^{16}$ Similarly, in a further study that evaluated 977 ETs performed by 6 physicians, no difference was found between them in terms of $\mathrm{CPR}^{5}$

Over the past 10 years, significant efforts have been made to develop standardized and atraumatic ET procedures to minimize the provider effect on CPR. ${ }^{6,19}$ In our IVF clinic, for example, a definitive procedure is implemented and performed by experienced and senior physicians; more specifically, USG is used to guide and expel the embryos into the endometrial cavity $\sim 10 \mathrm{~mm}$ from the uterine fundus on full bladder. Although ET is always performed by an experienced physician, it should be kept in mind that there are many possible confounding factors that can alter CPR, such as the presence of blood or mucus. These were excluded from the present study. Ultimately, there was no difference between the groups in terms of confounding factors. We subsequently explored the effects of different ET physicians in IVF-ICSI treatment, and found that it has no effect on CPR.

The strong point of the present study consists of its prospective design, the adequate number of subjects in each group, and the prototypical sample from central Turkey. The results can be generalized to most of the population of the country. However, the potential limitations of the study are that it was conducted in a tertiary care institution and that the cumulative CPR was not evaluated because no frozen ETs were included.

\section{Conclusion}

In conclusion, our data show that the pregnancy rates of patients who underwent IVF-ICSI treatment at our clinic were not impacted by the physician factor of who transferred the embryos.

\section{Contributors}

All authors participated in the concept and design of the study, as well as in the analysis and interpretation of data; draft or revision of the manuscript; and they have approved the manuscript as submitted. All authors are responsible for the reported research. 
24 Effect of the Physician Performing Embryo Transfer in IVF-ICSI Treatment Inal et al.

\section{Conflict of Interests}

The authors have no conflict of interests to declare.

\section{References}

1 Oruç AS, Yılmaz N, Görkem U, Inal HA, Seçkin B, Gülerman C. Influence of ultrasound-guided artificial insemination on pregnancy rates: a randomized study. Arch Gynecol Obstet. 2014;289 (01):207-212. Doi: 10.1007/s00404-013-2965-y

2 Inal ZO, Gorkemli $\mathrm{H}$, Inal HA. The effect of local injury to the endometrium for implantation and pregnancy rates in ICSI-ET cycles with recurrent implantation failure: a randomised controlled study. Eur J Gen Med. 2012;9(04):223-229

3 Yilmaz N, Kahyaoglu İ, İnal HA, Görkem Ü, Devran A, Mollamahmutoglu L. Negative life events have detrimental effects on invitro fertlization outcome. Hum Fertil (Camb). 2015;18(03): 220-224. Doi: 10.3109/14647273.2015.1022607

4 Inal HA, Yilmaz N, Gorkem U, Oruc AS, Timur H. The impact of follicular fluid adiponectin and ghrelin levels based on BMI on IVF outcomes in PCOS. J Endocrinol Invest. 2016;39(04):431-437. Doi: $10.1007 / \mathrm{s} 40618-015-0392-6$

5 van Weering HG, Schats R, McDonnell J, Hompes PG. Ongoing pregnancy rates in in vitro fertilization are not dependent on the physician performing the embryo transfer. Fertil Steril. 2005;83 (02):316-320. Doi: 10.1016/j.fertnstert.2004.07.957

6 Yao Z, Vansteelandt S, Van der Elst J, Coetsier T, Dhont M, De Sutter P. The efficacy of the embryo transfer catheter in IVF and ICSI is operator-dependent: a randomized clinical trial. Hum Reprod. 2009;24(04):880-887. Doi: 10.1093/humrep/den453

7 Yılmaz N, Oruç AS, Zeyrek T, Görkem U, Inal HA, Engin-Üstün Y, et al. Effect of the afterloaded external guidance embryo transfer technique on pregnancy rates in single embryo transfer cycles. J Turk Ger Gynecol Assoc. 2013;14(03):153-156. Doi: 10.5152/ jtgga.2013.49225

8 Ozturk Inal Z, Yilmaz N, Inal HA, Hancerliogullari N, Coskun B. Are there any differences between antagonist administration on days $<6$ and $\geq 6$ of Controlled Ovarian Hyperstimulation on assisted reproductive technique outcomes? J Chin Med Assoc. 2018;81 (01):53-57. Doi: 10.1016/j.jcma.2017.01.011

9 Inal ZO, Inal HA, Aksoy E, Kucukkendirci H. Spermiogram test results of patients presenting to our IVF Center due to infertility. J Clin Anal Med.. 2017;8(05):365-369. Doi: 10.4328/JCAM.4891
10 Inal ZO, Inal HA, Erdem S. The effect of serum and follicular fluid secreted frizzle-related protein-5 on in vitro fertilization outcomes in patients with polycystic ovary syndrome. Mol Biol Rep. 2018;45(06):2037-2044. Doi: 10.1007/s11033-018-4360-z

11 Barber D, Egan D, Ross C, Evans B, Barlow D. Nurses performing embryo transfer: successful outcome of in-vitro fertilization. Hum Reprod. 1996;11(01):105-108. Doi: 10.1093/oxfordjournals.humrep.a018999

12 Karande VC, Morris R, Chapman C, Rinehart J, Gleicher N. Impact of the "physician factor" on pregnancy rates in a large assisted reproductive technology program: do too many cooks spoil the broth? Fertil Steril. 1999;71(06):1001-1009. Doi: 10.1016/ s0015-0282(99)00139-9

13 Papageorgiou TC, Hearns-Stokes RM, Leondires MP, Miller BT, Chakraborty P, Cruess D, et al. Training of providers in embryo transfer: what is the minimum number of transfers required for proficiency? Hum Reprod. 2001;16(07):1415-1419. Doi: 10.1093/humrep/16.7.1415

14 Visser DS, Fourie FL, Kruger HF. Multiple attempts at embryo transfer: effect on pregnancy outcome in an in vitro fertilization and embryo transfer program. J Assist Reprod Genet. 1993;10 (01):37-43. Doi: 10.1007/BF01204438

15 Wisanto A, Janssens R, Deschacht J, Camus M, Devroey P, Van Steirteghem AC. Performance of different embryo transfer catheters in a human in vitro fertilization program. Fertil Steril. 1989; 52(01):79-84. Doi: 10.1016/s0015-0282(16)60793-8

16 Angelini A, Brusco GF, Barnocchi N, El-Danasouri I, Pacchiarotti A Selman HA. Impact of physician performing embryo transfer on pregnancy rates in an assisted reproductive program. J Assist Reprod Genet. 2006;23(7-8):329-332. Doi: 10.1007/s10815-006-9032-6

17 Hearns-Stokes RM, Miller BT, Scott L, Creuss D, Chakraborty PK, Segars JH. Pregnancy rates after embryo transfer depend on the provider at embryo transfer. Fertil Steril. 2000;74(01):80-86. Doi: 10.1016/s0015-0282(00)00582-3

18 Bjuresten K, Hreinsson JG, Fridström M, Rosenlund B, Ek I, Hovatta O. Embryo transfer by midwife or gynecologist: a prospective randomized study. Acta Obstet Gynecol Scand. 2003;82(05): 462-466. Doi: 10.1034/j.1600-0412.2003.00128.x

19 van de Pas MM, Weima S, Looman CW, Broekmans FJ. The use of fixed distance embryo transfer after IVF/ICSI equalizes the success rates among physicians. Hum Reprod. 2003;18(04):774-780. Doi: 10.1093/humrep/deg175 